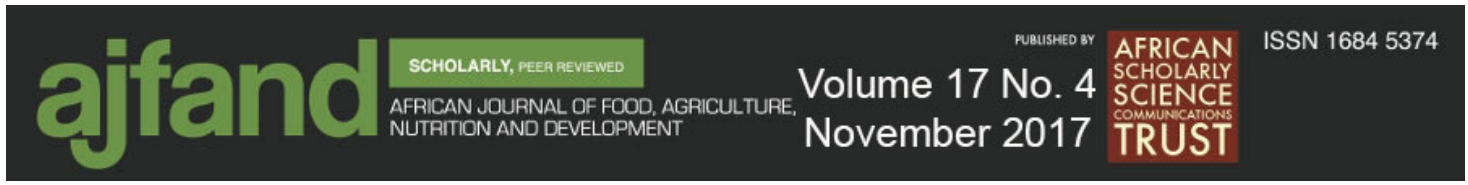

\title{
PHYSICO-CHEMICAL CHARACTERISTICS AND FATTY ACID PROFILE OF BAILLONELLA TOXISPERMA Pierre TRADITIONALLY EXTRACTED EDIBLE OIL FROM CAMEROON FORESTS
}

Fungo $\mathrm{R}^{1,2,3^{*}}$, Ngondi $\mathrm{JL}^{4}$, Muyonga $\mathrm{JH}^{1}$, Tchatat $\mathrm{M}^{5}$, Odjo $\mathrm{S}^{6}$ and $\mathrm{JC}$ Tieguhong ${ }^{2}$

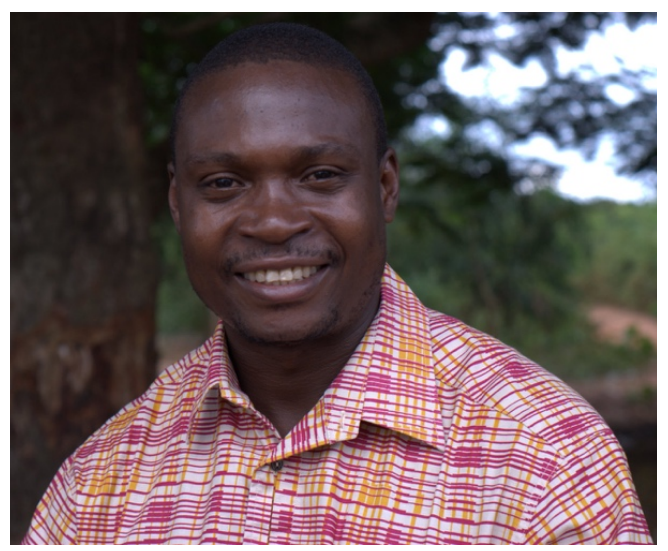

Robert Fungo

"Corresponding author email: rfungom@yahoo.com

${ }^{1}$ School of Food Technology, Nutrition \& Bio-Engineering, Makerere University, P. O. Box, 7062, Kampala, Uganda

${ }^{2}$ Bioversity International Forest Genetic Resources Programme Via dei Tre Denari, 472/a 00057 Maccarese, Rome, Italy

${ }^{3}$ FAO Ethiopia CMC Road, Bole Sub City, Kebele 12/13 P O Box 5536, Addis Ababa, Ethiopia (current address)

${ }^{4}$ Department of Biochemistry, University of Yaounde 1, Yaoundé, Cameroon

${ }^{5}$ Institut de Recherche Agricole pour le Développement, Yaoundé Cameroon. P.O Box 2067 Yaoundé Cameroon

${ }^{6}$ University of Liege, Gembloux Agro-Bio Tech, Passage des Déportés, 2, B-5030 Gembloux, Belgium 


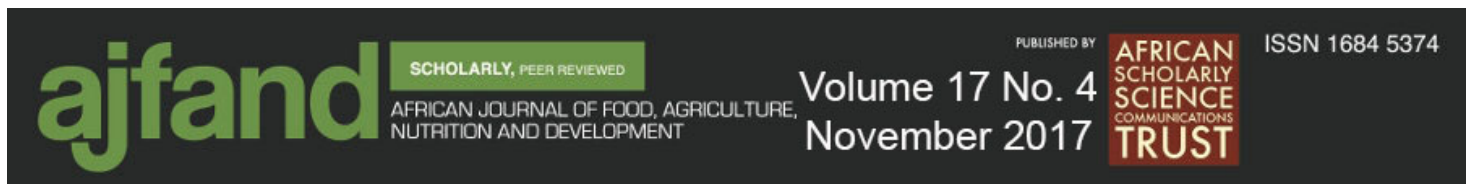

\begin{abstract}
Baillonella toxisperma Pierre oil is an edible oil obtained from the seeds of wildly growing timber producing $B$. toxisperma tree species in Cameroon and the rest of the Congo Basin forests of West and Central Africa. This oil can be an important source of fat that can be used as a source of food to humans and/or a source of raw materials in the cosmetics, pharmaceutical and nutraceutical industries, to produce important commercial products. In the present study, samples of the seeds of $B$. toxisperma were harvested from three representative villages, each from the site in South and East of Cameroon. Seed oil was extracted using the traditional extraction method of B. toxisperma oils in rural Cameroon. Physico-chemical characteristics including colour, refractive index, viscosity, oil yield, acid value, peroxide value, saponification value, iodine value and $\alpha$ tocopherols and fatty acid composition of crude oil of $B$. toxisperma nuts were all investigated. The oil yields from these seeds ranged from $38.2 \%$ to $45.6 \%$. The peroxide, saponification and iodine values ranged from 2.13 to $2.69 \mathrm{mEq} / \mathrm{kg}, 182.13$ to $188.30 \mathrm{mg}$ $\mathrm{KOH} / \mathrm{g}$ and 54.41 to $57.98 \mathrm{I} 2 \mathrm{~g} / 100 \mathrm{~g}$, respectively. The highest acid value and $\alpha$ tocopherols were $14.87 \mathrm{mg} \mathrm{KOH} / \mathrm{g}$ and $24.3 \mathrm{mg} / 100 \mathrm{~g}$, respectively. The main fatty acids of Baillonella toxisperma Pierre oils were oleic, stearic and palmitic acids. Linoleic acid contents varied between $58.6 \%$ and $56.97 \%$. The ratio of unsaturated to saturated fatty acids content in these oils was $2: 1$. The fact that the physico-chemical characteristics and fatty acid profile are comparable to common vegetable oils shows that the $B$. toxisperma oil of the researched species from Cameroon is a potential source of valuable oil which might be used for edible, cosmetic, pharmaceutical and other industrial applications. This characterization is a bench mark for monitoring the quality of Baillonella toxisperma Pierre oil, from Cameroon and can be used to enhance its local and international trade.
\end{abstract}

Key words: Congo Basin, Baillonella toxisperma Pierre Oil, Fatty Acid, Physicochemical 


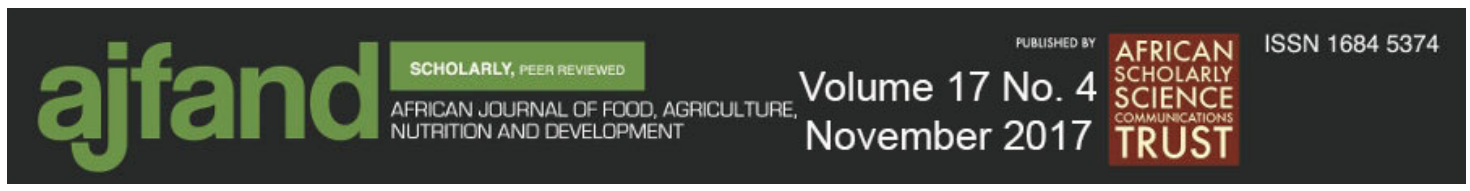

\section{INTRODUCTION}

Baillonella toxisperma Pierre is a large low land rain forest multi-purpose tree species that is inhabitant of the Congo Basin forests, stretching from South East Nigeria, through Cameroon, Gabon to the Democratic Republic of Congo and to a lesser extent to some parts of North Angola and Equatorial Guinea [1, 2, 3, 4]. The presence of B. toxisperma in some regions acts as a marker for past human settlement, probably as a result of its usefulness and value to past residents in forests [2]. Recent reports indicate that this tree is a major cause of disputes in Cameroon and Nigeria [4, 5]. It is a major timber producing tree, resulting in conflict between the commercial logging companies and the local communities who extract edible oil from its seeds, presenting forest conservation issues [4]. As a result, logging concessionaires put livelihoods of forest dependent populations at risk when exploiting timber species $[1,2,6]$. The continued existence and accessibility of $B$. toxisperma species, are also tied to the issue of perpetuating traditional lifestyles, because of its importance in the local economy (both barter and cash) of forest people in Nigeria and Cameroon [5, 7].

Baillonella toxisperma produces seeds with a yellowish succulent pulp popularly eaten fresh as a snack by children and adults going about their work $[5,7,8]$. The seeds also contain a nut that is processed to produce edible oil which is sold by forest communities. According to findings by Fungo et al. [5], about $69 \%$ of the Cameroon forest populations process $B$. toxisperma into edible oil, a more valuable product for consumption and income security. Edible oil from $B$. toxisperma is reported to be rich in crude fat, which ranges from $6.13 \mathrm{mg} / 100 \mathrm{~g}$ [9] to $9.25 \mathrm{mg} / 100 \mathrm{~g}$ [3]. Fungo et al. [3] further reported that the oil contains total digestible carbohydrates $(84.18 \mathrm{mg} / 100 \mathrm{~g}), \mathrm{Ca}(37.5 \mathrm{mg} / 100 \mathrm{~g})$ and Fe $(3.3 \mathrm{mg} / 100 \mathrm{~g})$. However, the fatty acid and physical-chemical content of these nuts are yet to be documented. Documenting the physico-chemical characteristics and fatty acid profile of locally extracted $B$. toxisperma oil will be useful to policy makers, nutritionists, development agencies and the general public in Cameroon and the entire Congo Basin forest region where $B$. toxisperma trees are readily available.

\section{MATERIALS AND METHODS}

Edible portions of readily available Baillonella toxisperma Pierre were sampled from six villages of Eastern (Melambo, Nkolbikong and Bonando) and Southern (Ngong, Bissam and Ondondo) sites in Cameroon. The villages from each site were selected on the basis of their accessibility and proximity to the annually allocated timber logging areas (Figure. 1).

\section{Sampling criteria}

A double stage cluster sampling technique involving one stage of purposeful selection and one stage of randomization was deployed. In the first stage, the most accessible administrative districts within each site and fitting the village selection criterion listed above were purposefully selected. In the second stage, three villages were randomly selected from the selected districts of each site. From the East, samples of B. toxisperma were collected from the villages of Bonando, Melambo and Nkolbikong while in the South edible portions were collected from the villages of Ngong, Ondondo and Bissam. 

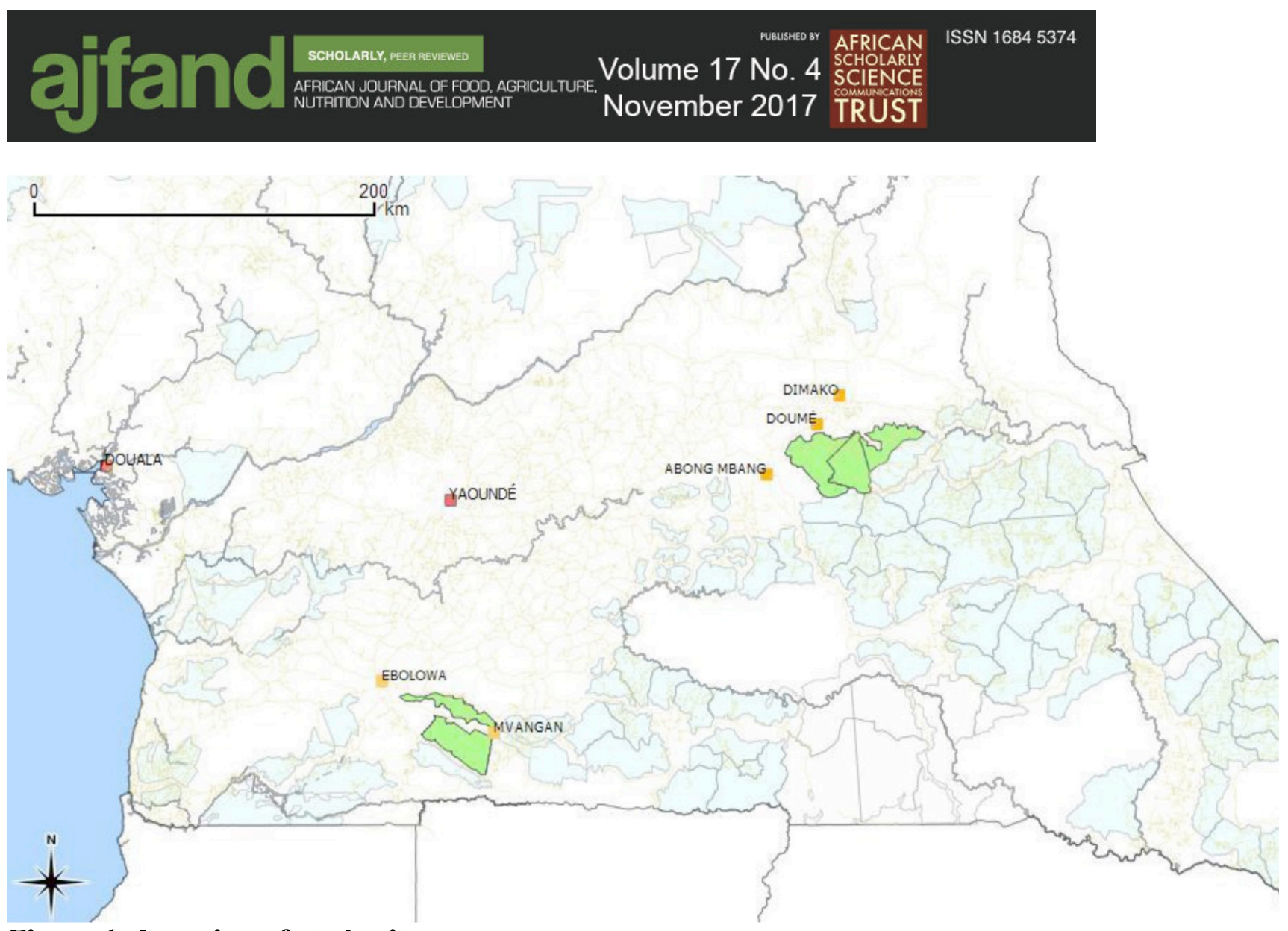

Figure 1: Location of study sites

\section{Traditional oil extraction procedure}

The traditional extraction method of B. toxisperma oil reported by Moss [10] among Cameroonian populations was adopted for this study (Figure 2). From each village, five fresh mature and ripe seeds that had naturally detached from their parent trees were picked from the ground with dirt removed and washed using running water $[3,8]$. In each village, the seeds were sampled from different points of the forest and collected in a perforated plastic container, labeled, kept in an ice box container and transported to the laboratory at Yaoundé I University in Cameroon to simulate the traditional oil extraction techniques (Figure 2). The pulp of the fresh seeds was removed using stainless knives exposing the seeds that were sun dried for 3-4 days. The dried seeds were crushed using pestles, separating the oil rich kernel nuts from the husks. The removed husks were used as fuel for the subsequent operations. The exposed kernel nuts per village were weighed $\left(\mathrm{M}_{1}\right)$ using an electronic balance. The nuts were placed in pan and roasted using a charcoal stove for about 15-20 minutes. This process denatures toxic and bitter substances such as saponins, with the residue nuts having a pleasant taste free from the bitterness $[10,11]$. The roasted nuts were subsequently pounded using a mortar and pestle producing small pieces. The resultant dough, in a pot placed on a charcoal stove, was then macerated with addition of hot water until oil residues separated by floating (malaxation process). The floating oil residues were poured in the middle of a clean white cloth, folded, then hand pressed and squeezed to sieve out the oil from residues. The resulting sieved oil was then heated to remove water molecules from the mixture. The extracted $B$. toxisperma oil was weighed and registered as $\mathrm{M}_{2}$. The oil yield content was determined gravimetrically and expressed as a percentage of the kernel weight using the 


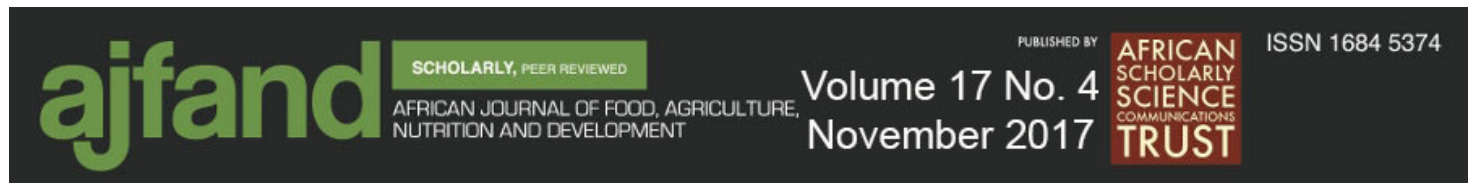

formula; Oil yield $=\left(\mathrm{M}_{2} / \mathrm{M}_{1}\right) \times 100 \%$. The oil was stored in a freezer $\left(-20^{\circ} \mathrm{C}\right)$ until it was required for further laboratory analyses.

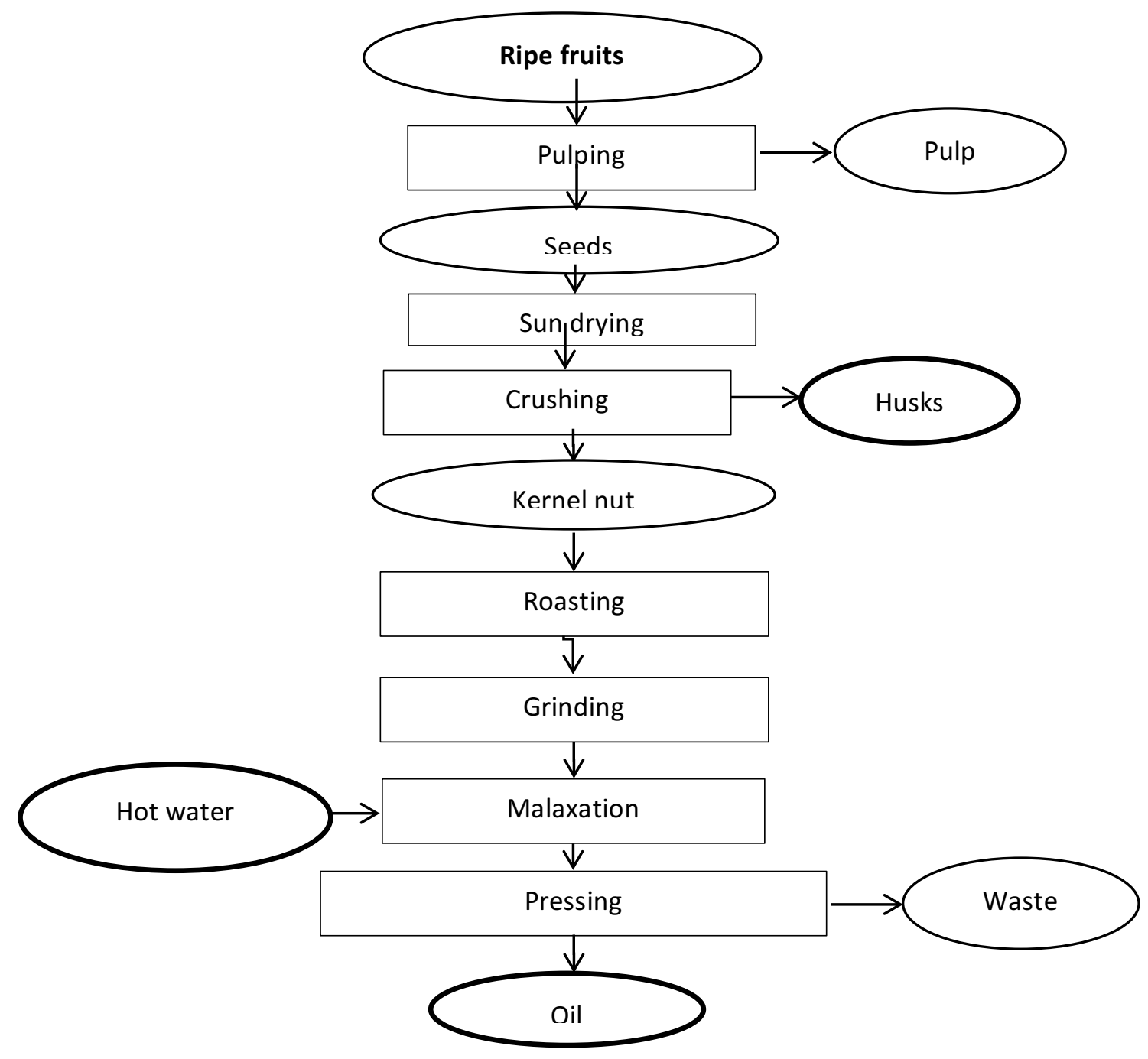

Figure 2: Flow chart of locally extracted edible oil from Baillonella toxisperma Pierre seeds

\section{Laboratory analysis of Baillonella toxisperma Pierre oil}

\section{Physico characteristics}

Refractive index and viscosity were determined using standard AOAC methods [12]. A viscometer (BROOKFIELD DV-11+Pro, USA) at 34-35oC and a refractometer (Bellingham + Stanley $(B+S)$, No. A86006, England) were used to determine viscosity and refractive index, respectively. 


\section{Chemical characteristics}

Acid, saponification, peroxide and iodine values were determined using standard AOAC methods [12].

The fatty acid profiles of Baillonella toxisperma Pierre oil were determined using the three stage trans-esterification method [13]. (i) Esterification of the fatty acids in the oil: Baillonella toxisperma Pierre oil sample of about $10.0 \mathrm{ml}$ was transferred into a $15 \mathrm{ml}$ glass tubes, followed by the addition of $1 \mathrm{ml}$ anhydrous methanol containing $2 \mathrm{M} \mathrm{HCl}$. The contents were flushed with nitrogen gas and the tubes closed tightly with teflon-lined screw caps. To achieve complete methanolysis, the glass tubes with the sample were placed in an oven with temperature set at $90^{\circ} \mathrm{C}$, for 2 hours after which the tubes were cooled to room temperature. (ii) Extraction of the fatty acid methyl esters (FAME): The cooled tubes were opened and the methanol mixed with the samples was evaporated to $0.5 \mathrm{ml}$ using a stream of nitrogen gas. An amount of $0.5 \mathrm{ml}$ of distilled water was added to the methanolised lipid fraction to reduce solubility of methyl esters in the methanol phase. The caps of the tubes were tightened and turned upside down to ensure uniform mixture of the contents for one minute, followed by centrifugation to separate the phases. The upper hexane layer containing fatty acid methyl esters was transferred carefully to a vial using a pipette. The water-methanol phase was extracted twice using $1 \mathrm{ml}$-hexane. (iii) High Performance Liquid Chromatography (HPLC) determination of fatty acid composition: One microlitre $(1 \mu \mathrm{l})$ of the mixed hexane extract was injected splitless (the split opening after $4 \mathrm{ml}$ ) in Elmer 8500 gas chromatograph equipped with a flame ionization detector (FID) on a $25 \mathrm{~m} \mathrm{x} 0.25 \mathrm{~mm}$ (i.d.) column coated with polyethylene glycol (PEG) as a stationary phase of $0.2 \mu \mathrm{m}$ thickness (CP-WAX 52CB Chrompack) and the mobile phase was hydrogenised at 20psi. The injector and detector temperatures were set at $260^{\circ} \mathrm{C}$ and $330^{\circ} \mathrm{C}$, respectively. The oven was programmed at $90^{\circ} \mathrm{C}$ for 4 minutes before cooling for the next run. By comparing the chromatographic peaks of the injected oil samples with the standard chromatograph of the mixture of 20 fatty acid methyl esters, HPLC reference standard 68D NuCheck-Prep (Elysian, Minn., USA), the oil samples were identified. To monitor the performance of the column, the standard mixture of the fatty acid methyl esters were chromatographed at regular intervals for tenth sample running. The amount of each fatty acid in the sample was expressed as \% of the sum of all fatty acids in the sample.

\section{Statistical analysis}

One-way analysis of variance (ANOVA) was performed and the least significant differences (LSD) were calculated. Significance was accepted at $\mathrm{P} \leq 0.05$. Results were expressed as mean \pm S.D.

\section{RESULTS}

\section{Oil yield}

The oil yield of Baillonella toxisperma Pierre ranged from 38.2 in Ngong to $45.6 \%$ in Bissam (Table 1). Generally on average oil yield was highest in the nuts sampled from the East (44.39\%) than from the South $(41.3 \%)$. 


\section{Physico-Chemical properties}

The physical characteristics revealed that viscosity ranged from $2.55 \mathrm{cP}$ (Melambo) to $2.73 \mathrm{cP}$ (Ondondo) and refractive index ranged from 1.46 (both Bissam and Bonando) to 1.47 in the rest of the villages (Table 2). Overall, the color of the extracted oil from all the six villages was yellowish. The chemical characteristics of B.toxisperma oil such as the peroxide, saponification and iodine values ranged from 2.13 to $2.69 \mathrm{mEq} / \mathrm{kg}, 182.13$ to $188.30 \mathrm{mgKOH} / \mathrm{g}$ and 54.41 to $57.98 \mathrm{I}_{2} \mathrm{~g} / 100 \mathrm{~g}$, respectively. The acid value was registered highest in oils of Bissam $(14.87 \mathrm{mgKOH} / \mathrm{g})$ and least in oils of Melambo (13.83 $\mathrm{mgKOH} / \mathrm{g})$. The $\alpha$-tocopherols content was registered highest $(24.3 \mathrm{mg} / 100 \mathrm{~g})$ in oils of Ondondo village and least $(18.08 \mathrm{mg} / 100 \mathrm{~g})$ in oils of Melambo village.

\section{Fatty acid profile}

Five major fatty acids in the oils were detected including palmitic, stearic, arachidic, oleic and linoleic acids (Table 3). The most predominant fatty acid was oleic, followed by stearic acid and palmitic acid. Small amounts of linoleic and arachidic acids were detected. The amount of unsaturated fats (oleic + linoleic) was higher $(57.8 \%)$ than saturated fats (palmitic + stearic + Arachidic) $(42.2 \%)$ giving unsaturated to saturated ratio of $2: 1$.

\section{DISCUSSION}

\section{Oil yield and physico-chemical properties of traditionally processed Baillonella Pierre toxisperma}

Baillonella toxisperma Pierre oil has been documented as one of the most important household sources of livelihoods in Cameroon and the rest of the Congo Basin countries $[5,7,8,14]$; thus its oil yield is an important characteristic to be considered during its promotion for consumption and conservation of the species. The increasing demand of this oil can be attributed to its high market value in Cameroon and neighboring countries, most especially among communities from South East Nigeria [7]. In the East of Cameroon demand for $B$. toxisperma oil exceeds availability [9], where it is largely used in household cooking, while the surplus is sold to middle men who sell it in Cameroonian cities, Nigeria and North of Gabon [8]. The oil yield in this study ranged from 38.2 to $45.6 \%$, with a mean of $42.8 \%$. Although this is the first study to document oil yield and physico-chemical characteristics of $B$. toxisperma oil, the yields registered in this study are comparable to oil yields of forest nuts. For example, Fungo et al. [3] reported an average oil yield of $38.7 \%$ in Pentaclethra macrophylla nuts from Cameroonian forests, while Okia et al. [15] reported an average oil yield of $44.5 \%$ in Balanites aegyptiaca nuts from Ugandan forests. The oil yields extracted using traditional means registered in the present study are an indication that $B$. toxisperma oil can easily be extracted from $B$. toxisperma nuts for use in comparison to vegetable oil. The variation in the $B$. toxisperma oil yields per region could be attributed to environmental influence, geographical location, agronomic factors, agro-climatic conditions and genetic variation [16]. The high oil yield content nuts sampled from the East of Cameroon could be attributed to the management practices of both logging concessionaires and communities in this region [8]. In the East of Cameroon, the regional government and the management practices of concessionaires have enforced protection of $B$. toxisperma trees from logging because of its high economic importance to the community [1]. This has resulted in immature seeds 
from these trees not being harvested. Then again, the percentage oil yield unrecoverable by traditional and mechanical expression techniques increases progressively as the oil content of the seeds decreases [16]. However, given the traditional oil extraction methods used in this study, there is need for a more efficient oil extraction technique, such as the solvent extraction methods used in extraction of industrial vegetable oils [17]. Also, despite high oil yields registered in this study, there is need for further studies to scientifically optimize maximum oil yields in $B$. toxisperma nuts, using traditional methods.

The color of B. toxisperma oil was yellowish; refractive index ranged from 1.46 to 1.47 , while viscosity of the oil varied between 2.55 and 2.73. Plenderleith and Brown [16] described the traditionally extracted $B$. toxisperma oil as a dark yellowish fluid while Fungo et al. [3] attributed the yellow color in $B$. toxisperma oil to presence of carotenoids. Carotenoids and their derivatives are responsible for the yellow color of fruits, vegetables, nuts, cereals and some crude oils [18]. The presence of carotene makes $B$. toxisperma oil nutritionally important because carotenoids are unsaturated hydrocarbons that act as antioxidants [3, 14]. The viscosity values obtained for $B$. toxisperma oil samples from the different villages in the two sites fall within the category of most oils earlier reported, while their refractive index values do not differ much from refractive indices of oil producing forest nuts such as P. macrophylla [19], bambara groundnut (Vigna subterranean) [20] and commercial vegetable oil producing crops such as sun flower, soya bean and palm oil [21]. Viscosity is one of the most important commercial quality parameters of oil [22]. Given that the refractive index and viscosity index values are comparable to those of soy oil and palm oil [21], B. toxisperma oil could be a suitable and potential resource for biodiesel production. However, as a result of conflict for $B$. toxisperma resources between forest populations and commercial logging companies [4], biodiesel viability of $B$. toxisperma oil could be hindered by the limited availability of $B$. toxisperma species in Cameroon and the entire Congo Basin forests. The saponification and iodine values registered in this study are within the range of most oils suitable for food and cosmetics. For example, the saponification values in this study are comparable to values reported in the common African oil producing foods such as ground nuts (188 to $196 \mathrm{mgKOH} / \mathrm{g}$ ) and corn (187-196 $\mathrm{mgKOH} / \mathrm{g})$ [23]. It is also similar to other typical commercial seed oils such as soya bean, castor, pea nut, cotton seed, sun flower and avocado oils whose average saponification values range from 175 to 250 $\mathrm{mgKOH} / \mathrm{g}$ [24]. The high saponification value indicated that oils are normal triglycerides, a factor considered in production of soap and shampoo. The B. toxisperma oil acid value obtained in this study is comparable to acid values of oil samples from forest nuts species such as Vitellaria paradoxa C.F. Gaertn [25], P. macrophylla [19] and Vigna subterranean [20]. As a result of the recalcitrant nature of $B$. toxisperma seeds, the quick germination may increase the free fatty acid of $B$. toxisperma oil. Free fatty acid of $B$. toxisperma ( 1 and $20 \%$ ) with a peroxide value of less than 10 registered in this study is the characteristic of the majority of many edible vegetable oils $[15,19,20,21$, 25]. Though $\alpha$-tocopherol represents lipid soluble anti-oxidants, the $B$. toxisperma oil in the present study contains low quantities of $\alpha$-tocopherol ranging between 18.08-24.29 $\mathrm{mg} / 100 \mathrm{~g}$. The low values of $\alpha$-tocopherol obtained in this study could have been a result of prolonged storage of $B$. toxisperma seeds, brought about by the long distances covered from the point of collection of the samples to the point of analyses at the biochemistry 
laboratory at Yaoundé I University. The $\alpha$-tocopherols might have degenerated under a chemical quenching process of oxidants (free radicals such as oxidized $\alpha$-tocopheroxyl) during the long storage times prior to the laboratory analysis [25]. Studies by Kornsteiner et al. [26] indicate that $\alpha$-tocopherol is one of the fat soluble vitamin E substances that cannot be synthesized by animals, making it imperative to be obtained from plant sources through diet.

\section{Fatty acid composition of $B$. toxisperma oil}

This study revealed that $B$. toxisperma oil consists of substantial amounts of fatty acids which could be of health benefit to those who consume it. The fatty acid profile of different food sources is important in determining the nutritional, health and commercial value of oils to humans [27]. The fatty acid composition of B. toxisperma oil revealed oleic acid as the predominant fatty acid. Four major fatty acids in the order oleic $>$ stearic $>$ palmitic $>$ arachidic were found in the analyzed oils from the six study subregions, with small quantities of linoleic acid in the samples registered. The mean fatty acid contents in this study were: oleic $57.52 \%$, stearic $36.32 \%$, palmitic $4.51 \%$, arachidic $0.5 \%$ and linoleic $0.34 \%$. The high level of unsaturated fatty acid oleic acid in $B$. toxisperma oil falls in the range reported in oils of Vitellaria paradoxa C.F. Gaertn (57\%) [25], while it is favorably comparable to that of Elaeis guineensis (36\%), and soya bean oil $(25 \%)[27,28,29]$. Although the unsaturated linoleic acid content in B. toxisperma oil was detected in minute quantities $(0.29-0.35 \%)$, this presents further opportunities for selection of improved species of $B$. toxisperma for future propagation trials. Linoleic acid is an essential fatty acid; its quantity in the different species [30] could play an important role in germplasm selection for future breeding programs of B. toxisperma. Studies indicate that linoleic is one of the most important polyunsaturated fatty acids in humans because of its prevention of non-communicable diseases such as stroke [30]. The fact that the ratio of unsaturated fatty acids to saturated fatty acids was $2: 1$ indicates that $B$. toxisperma oil is a good source of the healthy unsaturated fatty acids. Notwithstanding, consumption of monounsaturated fatty acids such as oleic acid $(>55 \%)$ has been correlated with reducing blood levels of low-density lipoprotein (LDL) cholesterol, thus lowering the risk of cardio- vascular diseases which are on the rise among urban populations in developing countries [25]. Therefore, B. toxisperma oil may offer an alternative source of dietary fat. On the other hand, previous studies have scientifically demonstrated how the saturated palmitic and stearic acid could be of potential health and commercial benefits to humans [31,32]. Clinical trials in American populations revealed that health benefits of palmitic acid are comparable to the benefits of oleic acid in terms of its effect on cholesterol and lipoprotein levels in serum, as well as eicosanoids [31, 32]. Also, the European Union Foods Standards body has recommended substitution of cocoa butter with affordable and readily available oils and butters, with high contents of stearic and palmitic acids, into the chocolate production [33]. This increase in the demand of the traditional oils such as $B$. toxisperma oil in the chocolate industry could lead to strengthening of the conservation efforts of $B$. toxisperma species, hence improving on the long term household income and health security for the Congo basin communities. 


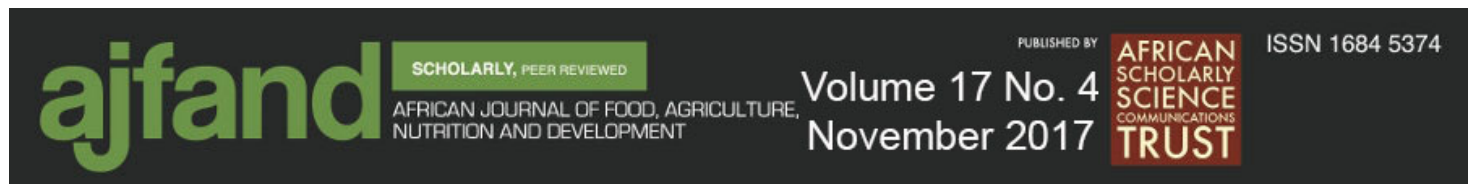

\section{CONCLUSIONS}

The results indicate that B. toxisperma oil yield is high $(42.8 \%)$ with good physicochemical properties and rich in unsaturated oleic acid and poly linoleic acid which are essential fatty acids. The order of fatty acids is oleic $>$ stearic $>$ palmitic $>$ arachidic. Unsaturated fatty acids (oleic and linoleic) constituted $57.8 \%$ of the oil making it nutritionally beneficial. The physico-chemical characteristics and fatty acid profile of $B$. toxisperma oil from Cameroon presented in this study make this oil a potential raw material for cosmetics, soap and food processing as an edible vegetable oil. However, there is a need to equip the rural forest communities with appropriate knowledge to promote conservation of these species of trees and techniques for increasing oil production hygienically in order to improve their livelihoods.

\section{ACKNOWLEDGEMENTS}

The authors wish to thank the Congo Basin Forest Fund (CBFF) of the African Development Bank and the CGIAR Research Programme on Forests, Trees and Agroforestry for the funding support 


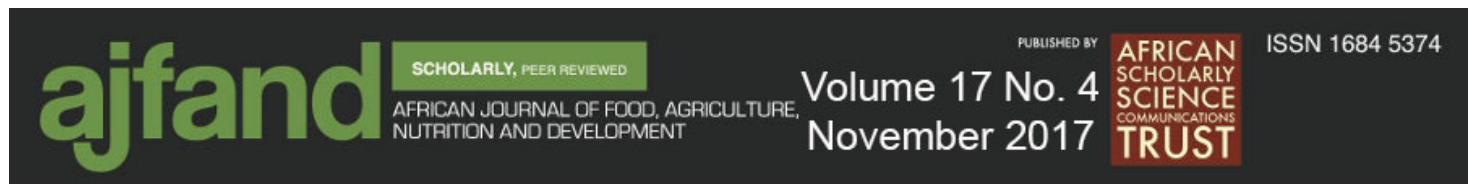

Table 1: Percentage oil yield of Baillonella toxisperma Pierre fruit seeds from six sites of East and South Regions of Cameroon ${ }^{a}$

\begin{tabular}{|c|c|c|c|c|c|c|}
\hline \multirow[b]{3}{*}{ Oil yield ${ }^{\mathrm{b}}(\%)$} & \multicolumn{6}{|c|}{ Region } \\
\hline & \multicolumn{3}{|c|}{ East } & \multicolumn{3}{|c|}{ South } \\
\hline & Melambo & Nkolbikong & Bonando & Ngong & Bissam & Ondondo \\
\hline Per site & 44.59 & 41.10 & 44.48 & 38.2 & 45.6 & 40.1 \\
\hline Average yield & & 44.39 & & & 41.3 & \\
\hline
\end{tabular}

${ }^{\mathrm{a}}$ Each value is the mean and standard deviation of 3 sample lots analyzed individually ${ }^{\mathrm{b}}$ Dry matter basis 


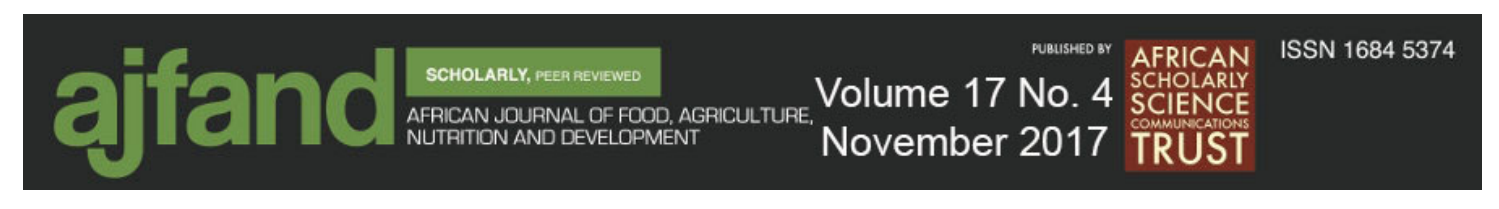

Table 2: Physico-chemical characteristics of traditionally extracted Baillonella toxisperma Pierre oil from six villages in South and East Cameroon $^{a}$

\begin{tabular}{|c|c|c|c|c|c|c|}
\hline \multirow{3}{*}{$\begin{array}{l}\text { Physico-chemical characteristics } \\
\text { (Mean } \pm \text { SD }\end{array}$} & \multicolumn{6}{|c|}{ Region } \\
\hline & \multicolumn{3}{|c|}{ South } & \multicolumn{3}{|c|}{ East } \\
\hline & Ngong & Bissam & Ondondo & Nkolbikong & Melambo & Bonando \\
\hline Peroxide value (mEq/kg) & $2.24 \pm 0.10$ & $2.69 \pm 0.09$ & $2.13 \pm 0.02$ & $2.18 \pm 0.07$ & $2.46 \pm 0.03$ & $2.31 \pm 0.21$ \\
\hline Saponification value (mgKOH/g) & $183.1 \pm 0.91$ & $188.30 \pm 0.51$ & $187.4 \pm 0.48$ & $182.13 \pm 0.01$ & $187.47 \pm 0.1$ & $182.48 \pm 0.81$ \\
\hline Acid value $(\mathrm{mgKOH} / \mathrm{g})$ & $14.27 \pm 0.91$ & $14.87 \pm 0.45$ & $14.17 \pm 0.05$ & $14.50 \pm 0.01$ & $13.83 \pm 0.05$ & $14.12 \pm 0.08$ \\
\hline$\alpha$-tocopherols (mg/100g) & $23.89 \pm 0.41$ & $22.07 \pm 0.02$ & $24.29 \pm 0.01$ & $20.14 \pm 0.01$ & $18.08 \pm 0.05$ & $21.15 \pm 0.07$ \\
\hline Viscosity (cP) & $2.71 \pm 0.14$ & $2.69 \pm 0.07$ & $2.73 \pm 0.01$ & $2.63 \pm 0.02$ & $2.55 \pm 0.01$ & $2.60 \pm 0.14$ \\
\hline
\end{tabular}

${ }^{\mathrm{a}}$ Each value is the mean and standard deviation of 3 sample lots analyzed individually

${ }^{\mathrm{b}}$ Dry matter basis 


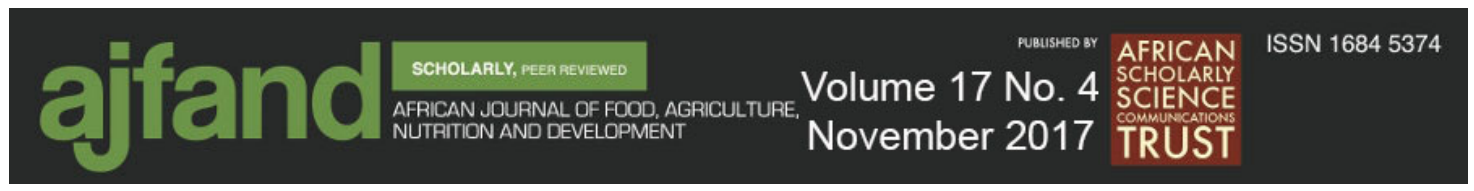

Table 3: Fatty acid profile of traditionally extracted Baillonella toxisperma Pierre oil from six villages in South and East of Cameroon ${ }^{\mathrm{a}}$

\begin{tabular}{lllllll}
\hline \multirow{2}{*}{$\begin{array}{l}\text { Mean } \\
\text { percentage fatty } \\
\text { acid }^{\mathbf{b}} \begin{array}{l}\text { Sean } \\
(\text { Mean } \pm \text { SD }\end{array}\end{array}$} & \multicolumn{5}{c}{ Region $^{\mathrm{c}}$} \\
\cline { 2 - 7 } & Ondondo & Bissam & Ndembo & Melambo & Nkolbikong & Bonando \\
\hline Palmitic & $4.27 \pm 0.04$ & $4.80 \pm 01$ & $4.67 \pm 0.09$ & $4.77 \pm 0.05$ & $4.03 \pm 0.17$ & $4.51 \pm 0.07$ \\
Stearic & $36.32 \pm 0.12$ & $35.21 \pm 0.71$ & $36.10 \pm 0.22$ & $37.60 \pm 0.37$ & $36.75 \pm 0.97$ & $35.91 \pm 14$ \\
Arachidic & $0.51 \pm 0.31$ & $0.48 \pm 0.24$ & $0.45 \pm 0.01$ & $0.65 \pm 0.01$ & $0.42 \pm 0.01$ & $0.54 \pm 0.02$ \\
Oleic & $57.04 \pm 0.61$ & $57.25 \pm 0.54$ & $58.60 \pm 0.43$ & $56.97 \pm 0.13$ & $58.26 \pm 01$ & $56.97 \pm 0.32$ \\
Linoleic & $0.34 \pm 0.04$ & $0.33 \pm 0.24$ & $0.29 \pm 0.01$ & $0.33 \pm 0.01$ & $0.35 \pm 0.01$ & $0.31 \pm 0.21$ \\
\hline
\end{tabular}

${ }^{a}$ Each value is the mean and standard deviation of 3 sample lots analyzed individually.

${ }^{b}$ Dry matter basis

${ }^{\mathrm{c}}$ The fatty acid values do not add up to $100 \%$ because some contents of fatty acids under investigation may not have been detected due to presence of minor compounds in the oils. Plant-based oils are composed of $100 \%$ triglycerides which include $95.6 \%$ fatty acids and $4.4 \%$ glycerol. The minor components of glycerol may not have been fully separated during extraction $[34,35]$ 


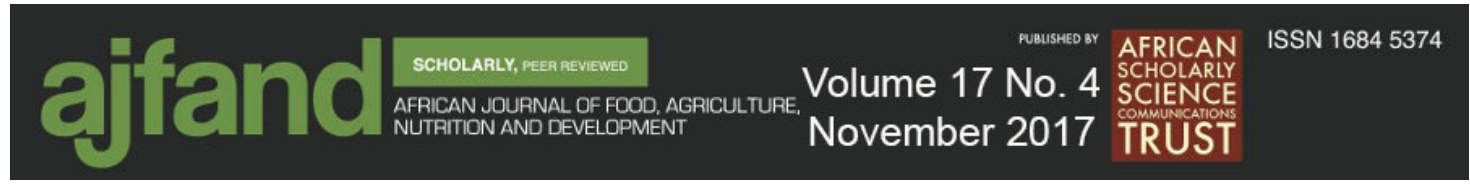

\section{REFERENCES}

1. Asseng Ze A Gestion durable des Produits Forestiers Non-Ligneux dans la concession forestie're de Pallisco. FAO, Etude pilote sur les techniques d'exploitation forestie're, no. 24 [Sustainable management of NTFPs in the Pallisco logging concession. FAO pilot study on logging techniques, no. 24], 2008.

2. Veuthey $\mathbf{S}$ and JF Gerber Logging conflicts in Southern Cameroon: a feminist ecological economics perspective. Ecological Economics. 2010; 70:170-177.

3. Fungo R, Muyonga J, Kaaya A, Okia C, Tieguhong JC and JJ Baidu-Forson Nutrient quality and bioactive compounds of Baillonella toxisperma, Trichoschypa abut and Pentaclethra macrophylla from Cameroon. Journal of Food Science and Nutrition. 2015; 3 (4): 292-301 doi: 10.1002/fsn3.217.

4. Snook L, Donn P, Dumini J, Fungo R, Kahindo JM, Loo J, Maukonen P, Iponga MD, Mikolo YC, Kameni MF, Muvatsi P, Ngondi J, Noutcheu R, Taedoumg H, Tchatat M, Tchingsabé $O$ and JC Tieguhong Trees for Food and Timber: are community interests in conflict with those of timber concessions in the Congo Basin? XIV WORLD FORESTRY CONGRESS, Durban, South Africa, 7-11 September 2015.

5. Fungo R, Muyonga JH, Kabahenda M, Okia CA and L Snook Factors influencing consumption of nutrient rich forest foods in rural Cameroon. Appetite. 2016; 97(1): 176-184 doi: 10.1016/j.appet.2015.12.005.

6. Ndoye $\mathbf{O}$ and JC Tieguhong Forest resources and rural livelihoods: the conflict between timber and non-timber forest products in the Congo Basin. Scandinavian Journal of Forest Research. 2004; 19 (4):36- 44.

7. Awono A, Djouguep A, Zapfack $\mathbf{L}$ and $\mathbf{O}$ Ndoye The potential of Irvingia gabonensis: can it contribute to the improvement of the livelihoods of producers in Southern Cameroon? International Journal of Sustainable Forestry. 2009; 2 (1):67-85.

8. Levang P, Lescuyer $G$, Noumbissi $D$, Dehu $C$ and $L$ Broussolle Does gathering really pay? Case studies from forest areas of the East and South regions of Cameroon. Forests, Trees and Livelihoods. 2014; 24(2): 128-143. http://dx.doi.org/10.1080/14728028.2014.1000980. (Accessed January 20 ${ }^{\text {th }}$ 2017)

9. Offem JO Chemical composition of the seeds of the timber tree, Mimusops djave, from south Eastern Nigeria. Tropical Science. 1990; 30: 207-210.

10. Moss $\mathbf{R}$ Underexploited tree crops: components of productive and more sustainable farming systems. Recherches systèmes en agriculture et 


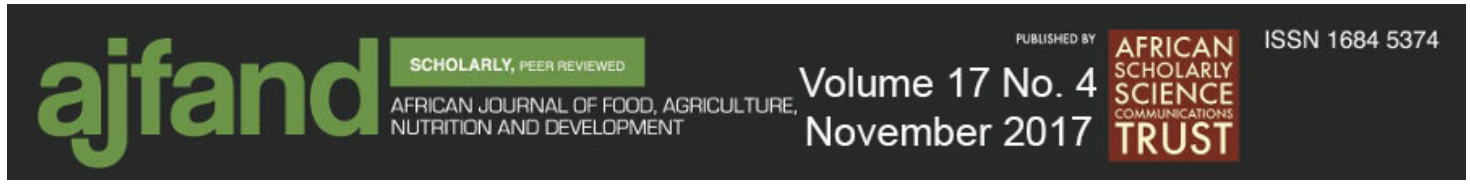

developement rural: Symposium International, Montpelier, France, CIRAD SAR, Montpellier, France, 1994.

11. Dalziel JM The Useful Plants of West Tropical Africa. Crown Agents for the Colonies. London, 1948: 52-560.

12. AOAC. Association of Official Analytical Chemists. Official Methods of Analysis, 18th edn. Washington, DC, 2006.

13. Joensen $\mathbf{H}$ and $\mathbf{O}$ Grahl-Nielsen Discrimination of Sebastes viviparus, $S$. marinus and $S$. mentella from Norway by chemometry of the fatty acid profile in heart and gill tissues in the skull- and otolith-oil. Comparative Biochemistry and Physiology part B: Biochemistry and Molecular Biology. 2001; 126: 69-79.

14. Fungo R, Muyonga J, Kabahenda M, Kaaya A, Okia C, Donn P, Tchtat M, Tchingsabe $\mathbf{O}$, Tieguhong JC, Loo J and L Snook Contribution of forest foods to women's nutrient intake and household food security in the biodiversity-rich Cameroonian forests. Public Health Nutrition. (2016); doi: 10.1017/S1368980016001324 (Accessed January $19^{\text {th }} 2017$ ).

15. Okia CA, Kwetegyeka J, Okiror $\mathbf{P}$, Kimondo JM, Teklehaimanot $\mathbf{Z}$ and $\mathbf{J}$ Obua Physico-chemical characteristics and fatty acid profile of desert date kernel oil in Uganda. African Crop Science Journal. 2012; 21 (S3): 723-734.

16. Plenderleith K and $\mathbf{N}$ Brown Moabi (Baillonella toxisperma). In: Clark LE. and Sunderland T. (Eds.). The Key Non-Timber Forest Products of Central Africa State of the Knowledge. USAID, 2004: 186.

17. Niir Board. Modern Technology of Oils, Fats and its Derivatives. Published by Asia Pacific Business Inc., Delhi-7, INDIA, 2002. 382.

18. WHO. Vitamin and mineral requirements in human nutrition. Appendix 1: Recommended nutrient intakes. 2004. WHO, Geneva, Switzerland.

19. Alinnor IJ and $\mathbf{R}$ Oze Chemical evaluation of the nutritive value of $P$. Macrophylla benth (African Oil Bean) Seeds. Pakistan Journal of Nutrition. 2011; 10: $355-359$.

20. Mazahib AM, Nuha MO, Salawa IS and EE Babiker Some nutritional attributes of Bambara groundnut as influenced by domestic processing. International Food Research Journal. 2013; 20 (3): 1165 - 1171.

21. Dhellot JR, Matouba E, Maloumbi MG, Nzikou JM, Safou-Ngoma DG, Linda M, Desobry S and M Parmentier Extraction, chemical composition and nutritional characterization of vegetable oils: Case of Amaranthus hybridus (Var1 and 2) of Congo Brazzaville. African Journal of Biotechnology. 2006; 5 (11):1095-1101. 
22. Chapagain BP, Yehoshua $\mathbf{Y}$ and $\mathbf{Z}$ Wiesman Desert date (Balanites aegyptiaca) Asan arid lands sustainable bioresource for biodiesel. Bioresource Technology. 2009; 100 (3):1221-1226.

23. Eromosele IC and CO Eromosele Studies on the chemical composition and physico-chemical properties of some wild plants. Plant Food Hum. Nutrition. 1993; (42): 251-258.

24. Welss TJ Food oils and their uses. 3rd ed. AVI Publishers, Westport 1983.

25. Okullo JBL, Omujal F, Agea JG, Vuzi PC, Namutebi A, Okello JBA and SA Nyanzi Physico-chemical characteristics of shea butter (Vitellaria paradoxa C.F. Gaertn.) oil from the shea districts of Uganda. African Journal of Food, Agriculture, Nutrition and Development. 2010; 10: 2070-2084.

26. Kornsteiner M, Wagner KH and I Elmadfa Tocopherols and total phenolics in 10 different nut types. Food Chemistry. 2005; 98: 381-387.

27. Ajayi IA, Oderinde RA, Kajogbola DO and JI Uponi Oil content and fatty acid composition of some underutilized legumes from Nigeria. Food Chemistry. 2006; 99 (1): 115-120.

28. Maritz FD, Hernadez R, Martinez G, Vidal G, Gomez M, Fernandez H and R Garces Comparative study of Ozonized olive oil and ozonized sun flower oil. Journal of Brazil Chemistry Society. 2006; 17 (2): 403-407.

29. Ezeagu IE, Gopal KAG, Khatoon $\mathbf{S}$ and $\mathbf{R}$ Gowda Physico-Chemical characterization of seed oil and nutrient assessment of Adenanthera pavonina: an underutilized tropical legume. Ecology of Food and Nutrition. 2004; 43 (4): 295305.

30. Uauy $\mathbf{R}$ Dietary fat quality for optimal health and well-being: Overview of recommendations. Annals of Nutrition and Metabolism. 2009; 54 (suppl1): 2 - 7.

31. Siri-Tarino PW, Sun Q, Hu FB and RM Krauss Meta-analysis of prospective cohort studies evaluating the association of saturated fat with cardiovascular disease. American Journal of Clinical Nutrition. 2010; 91: 535-546 [PMID: 20071648 DOI: 10.3945/ajcn.2009.27725].

32. Ng TK, Hayes KC, DeWitt GF, Jegathesan M, Satgunasingam N, Ong AS and D Tan Dietary palmitic and oleic acids exert similar effects on serum cholesterol and lipoprotein profiles in normocholesterolemic men and women. Journal of the American College of Nutrition. 1992; 11: 383-390 [PMID: 1506599 DOI: 10.1080/07315724.1992.10718241.

33. FOLD N Transnational sourcing practices in Ghana's perennial crop sectors. Journal of Agrarian Change. 2008; 7 (1):94-122. 


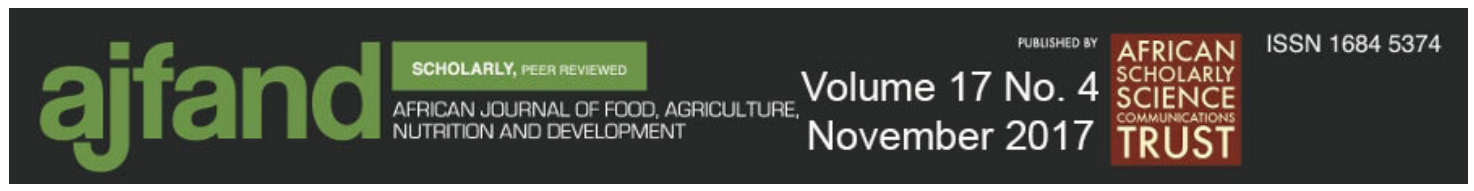

34. Spector AA and MA Yorek Membrane lipid composition and cellular function. Journal of Lipid Research. 1985; 26: 1015-1035.

http://www.jlr.org/content/26/9/1015.full.pdf + html Accessed January $20^{\text {th }}$ 2017).

35. Tvrzicka E, Kremmyda LS, Stankova B and A Zak Fatty acids as biocompounds: Their role in human metabolism, health and disease: A review. Part 1: Classification, dietary sources and biological functions. Biomedical. Papers. Medical. Faculty. University of Palacky Olomouc Czech. Republic. 2011; 155: $117-130$. 